Original Research Paper

\title{
Combination of Pumpkin Flour (Cucurbita moschata D.) and Carrot Flour (Daucus carota L.) on The Brightness Color of Koi Fish (Cyprinus carpio)
}

\author{
M. Riswan Maulana ${ }^{1}$, Muhammad Junaidi ${ }^{1}$, Bagus Dwi Hari Setyono ${ }^{{ }^{*}}$ \\ ${ }^{1}$ Department of Fisheries and Marine Science, Mataram University, Mataram, Indonesia
}

\begin{abstract}
Article History
Received : January $01^{\text {th }}, 2021$

Revised : January $07^{\text {th }}, 2021$

Accepted : January $17^{\text {th }}, 2021$

Published : January $21^{\text {th }}, 2021$

*Corresponding Author:

Bagus Dwi Hari Setyono

${ }^{1}$ Department of Fisheries and

Marine Science, Mataram

University, Mataram, Indonesia

Email:

bagus.setyono@unram.ac.id
\end{abstract}

\begin{abstract}
Koi fish is one of the freshwater ornamental fish that has an attractive body color, so the color disorder needs attention. The natural feed for pumpkin flour combined with carrot flour in artificial feed aims to improve the color quality of the koi fish. The study used a completely randomized design design (CRD) with 5 treatments and 3 replications so that 15 experimental units were obtained, each experimental unit contained 10 koi fish, and there were 5 treatments; P0 100\% Pellets, P1 contains 90\% Pellets $+3 \%$ LK Flour + TW 7\%, P2 contains 90\% Pellets + 4\% LK Flour $+6 \%$ W Flour, P3 contains 90\% Pellets + 5\% LK Flour + W 5 Flour \%, P4 contains $90 \%$ Pellets $+6 \%$ LK Flour $+4 \%$ W Flour. In this study, the highest increase in color value in koi fish occurred in the P4 treatment with the addition of a combination of $6 \%$ pumpkin flour and $4 \%$ carrot flour. The parameters in the study were the increase in color quality, increase in length and weight of koi fish, SR, and water quality. Observation data were analyzed using analysis of variance (ANOVA).
\end{abstract}

Keywords: Color Quality, Koi Fish Cyprinus carpio

\section{Introduction}

Ornamental fish is a fishery commodity that has the opportunity to be developed. Koi fish (Cyprinus carpio) is a freshwater ornamental fish that is popular with people today. The attractiveness of koi fish can be measured by its brilliant color, physical shape and completeness, behavior, and health condition or stamina. The high demand for koi fish must be followed by cultivation activities so that it can meet the needs in quality and quantity. Efforts made to assist aquaculture activities in order to obtain koi fish that are of good quality must be supported by the provision of quality and high protein feed.

The economic value of koi fish is very much influenced by the quality of the color it has, but the color can fade or disappear if the feed given is not in accordance with their needs. To be able to maintain and improve the color quality of koi fish, one way that can be done is through feed improvement. According to Nazhira (2017), fish need to be given food that can support the brightness of their color because food factors have an influence on the formation of ornamental fish color. Currently there are various brands of commercial feed for koi fish on the market and contain sufficient nutrients, but have a high price. One alternative to commercial feed is to provide additional ingredients containing carotenoids. Carotenoids are color-forming pigments found in many types of plants such as fruits and vegetables (Gunawan, 2005).

Carotenoids can be found in carrots and pumpkin. Carrots (Daucus carota L.) are tubers which are usually reddish yellow or yellowish orange in color. The orange color of carrots indicates that they are high in $\beta$-carotene. Carrots rich in $\beta$-carotene can improve color in Pirnia fish (Shadi 2015). Yellow squash, (Cucurbita moscahataD.) Is a type of fruit vegetable that has high durability and a source of vitamin A because besides being rich in carotene, pumpkin is also rich in carbohydrates, protein, minerals and vitamins. Yellow squash can be used as an alternative as an additional ingredient in the manufacture of fish feed or pellets which aim to increase the brightness of the fish color (Utami, 2012). 


\section{Materials and Methods}

This research was conducted on 17 August 2020-15 September 2020 for 30 days, at the Laboratory of the Aquaculture Study Program, Mataram University.

This study used an experimental method with a completely randomized design pattern (CRD) with 5 treatments and 3 replications in order to obtain 15 experimental units.

Treatment $0(\mathrm{P} 0) \quad=100 \%$ Pellets

Treatment $1(\mathrm{P} 1) \quad=90 \%$ Pellets + Pumpkin

Flour 3\% + Carrot Flour $7 \%$

Treatment $2(\mathrm{P} 2) \quad=90 \%$ Pellets + Pumpkin Flour 4\% + Carrot Flour $6 \%$

Treatment $3(\mathrm{P} 3) \quad=90 \%$ Pellets + Pumpkin Flour 5\% + Carrot Flour $5 \%$

Treatment $4(\mathrm{P} 4) \quad=90 \%$ Pellets + Pumpkin Flour 6\% + Carrot Flour $4 \%$.

\section{Research Procedure Preparation of Containers}

The maintenance container that will be used is an aquarium of 15 units with a length of $20 \mathrm{~cm}$, a width of $20 \mathrm{~cm}$ and a height of $20 \mathrm{~cm}$ which will then be filled with water with a volume of 20 liters and the stocking density of fish in each aquarium of 10 fish / aquarium. Before using the aquarium, first clean the dirt by washing the aquarium with soap and rinsing it with fresh water and then leaving it for 24 hours before using the aquarium.

\section{Feed Preparation}

The feed given during the study was commercial ornamental fish feed mixed with pumpkin flour combined with carrot flour according to each treatment. There are 5 treatments, namely P0 100\% Pellets, P1 contains 90\% Pellets + Pumpkin Flour 3\% + Carrot Flour 7\%, P2 contains 90\% Pellets + Pumpkin Flour $4 \%+$ Carrot Flour 6\%, P3 contains 90\% Pellets + Pumpkin Flour 5\% + Carrot Flour 5\%, P4 contains 90\% Pellets + Pumpkin Flour 6\% + Carrot Flour $4 \%$. The stages of mixing flour in feed are mixing each flour with progol (2-3 g/kg of feed) in one container and stirring until evenly distributed, adding water at a dose of $150 \mathrm{ml} / \mathrm{kg}$. Feed is given 2 times a day at 08.00 and 16.00 WITA.

\section{Preparation of Test Animals}

The test animals to be used were 150 koi fish (Cyprinus carpio). Before raising the fish in the research vessel, the acclimatization is carried out for 2-3 days. Acclimatization is a process of adjusting to different environmental conditions so that these conditions do not cause stress to fish (Arianto et al., 2018). Adaptation of feeding is also carried out so that the fish being kept are accustomed to the feed given. In addition, these fish are also measured for color brightness and body weight first as initial research data before being given treatment.

\section{Research Parameters Observation of Fish Color Brightness}

Measurements to measure the color of the fish were carried out every 10 days for one month. Prior to color observation, visual observations were made using photographs digital yang akan dilanjutkan dengan Color analysis based on scale and percentage using Adobe Photoshop CS4 software. To take photos of the fish that will be observed, the photo is taken in a studio box so that the photos obtained are better. The picture of the fish to be taken is within $10 \mathrm{~cm}$ from the end of the studio box. This is done so that the photos obtained have the same image quality. Taking pictures is done using the camera through the hole in the studio box (Putri, 2018).

Information:

$$
\mathbf{P C}=\mathbf{C t}-\mathbf{C O}
$$

$\mathrm{PC} \quad=$ Color enhancement $(\%)$

$\mathrm{Ct}=$ The final color value of the study $(\%)$

$\mathrm{C} 0=$ The initial color value of the study $(\%)$

\section{Survival Rate (SR)}

Survival Rate (SR) is obtained based on the equation stated by Effendi et al. (1997) in Putri (2018), namely:

Information:

$$
\mathrm{SR}=\left[\frac{\mathrm{Nt}}{\mathrm{N} 0}\right] \times 100 \%
$$

$$
\begin{array}{ll}
\mathrm{SR} & =\text { Survival Rate }(\%) \\
\mathrm{Nt} & =\text { Final number of fish (ekor) }
\end{array}
$$


N0 = Number of initial fish (ekor)

\section{Absolute Growth Observations}

The absolute growth measured was the absolute length growth and the absolute weight growth. According to Effendi (1979) in Putri (2018) the formula for measuring absolute weight is as follows:

$$
\mathbf{W m}=\mathbf{W t}-\mathbf{W o}
$$

$\mathrm{Wm}=$ Fish absolute weight gain $(\mathrm{g})$

$\mathrm{Wt} \quad=$ Final fish weight $(\mathrm{g})$

W0 = Initial fish weight $(\mathrm{g})$

Absolute length growth is calculated using the formula according to Roundsefell and Everhart (1962) in Putri (2018):

$$
\mathbf{L m}=\mathbf{L t}-\mathbf{L O}
$$

Information:

$\mathrm{Lm} \quad=$ Absolute length growth $(\mathrm{cm})$

$\mathrm{Lt} \quad=$ Final average length $(\mathrm{cm})$

L0 = Initial average length $(\mathrm{cm})$

\section{Water quality}

The measured water quality is carried out 3 times or once every ten days. The water quality was measured in the form of temperature, degree of acidity $(\mathrm{pH})$, and DO (Dissolved Oxygen) using tools in the form of a thermometer, $\mathrm{pH}$ meter, and DO test kit.

\section{Data analysis}

Data analysis carried out in this study included water quality, absolute growth, specific growth, and survival. The data were tested using Analysis of Variance (ANOVA) at the 95\% confidence level through the SPSS program to determine the effect of each treatment. If the results show different facts, an honest real difference test $(\mathrm{BNJ})$ will be carried out to see the best treatment.

\section{Results and Discussion}

\section{Improved Color Quality}

Based on the results of analysis of variance (ANOVA) at the 95\% confidence level, it showed that the increase in color quality in the combination treatment of pumpkin flour and carrots showed significantly different results between treatments. The results of data analysis in graphical form can be seen in Figure 1.

Figure 1. The Value of Increased Brightness of Koi Fish Color

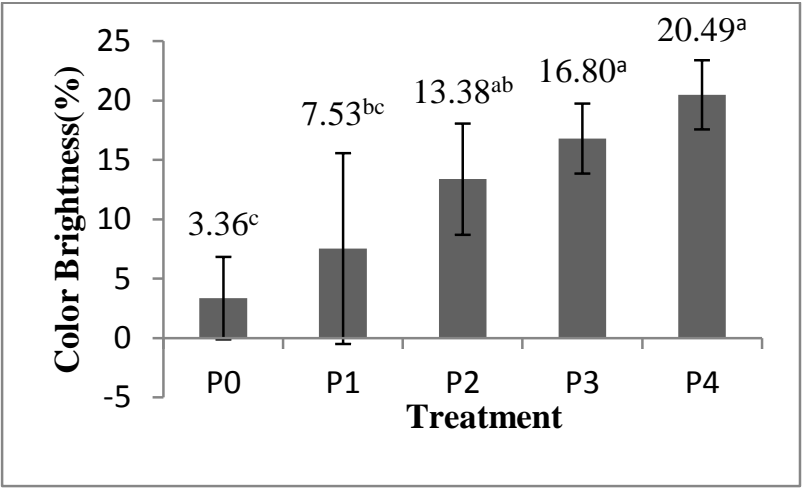

Information: *) numbers followed by the same letter in the same column show that they are not significantly different \pm ) indicates the standard deviation value.

The highest color quality improvement was found in the $\mathrm{P} 4$ treatment with the addition of a combination of $6 \%$ pumpkin flour with $4 \%$ carrot flour at $20.49 \%$, then $\mathrm{P} 3$ with the addition of a combination of 5\% pumpkin flour with 5\% carrot flour at $16.80 \%$, then $\mathrm{P} 2$ with the addition of a combination of $4 \%$ pumpkin flour with $6 \%$ carrot flour at $13.38 \%$, then in the P1 treatment with the addition of a combination of $3 \%$ pumpkin flour with $7 \%$ carrot flour at $7.53 \%$ and the lowest color quality level was in the P0 treatment without addition of a combination of pumpkin flour and carrot flour by $3.36 \%$.

The increase in color in koi fish is due to the addition of a combination of pumpkin flour and carrots in commercial feed, because pumpkin and carrot flour contain carotenoids which can make the koi fish brighter in color. The source of carotenoids for fish is known to be found in many plants. Some plants that have a high carotenoid content are pumpkin and carrots. Yellow squash is a type of fruit vegetable that has high durability and a source of vitamin A because it is rich in carotene, carbohydrates, protein, minerals and vitamins. The carotene content in pumpkin is very high, namely $180.00 \mathrm{SI}$ (Lestari, 2011). The orange color of carrots indicates a high betacarotene content. According to Slamet (2011) carrots are also one of the most important sources 
of provitamin A, the level of vitamin A in carrots is $12,000 \mathrm{SI}$.

The high color absorption of P4 treatment flour with the addition of a combination of pumpkin $6 \%$ pumpkin and $4 \%$ carrots is suspected because the dose given is in accordance with the needs of the fish to improve color quality. This statement is in accordance with Azuri (2018) that adding an excessive amount of carotenoids in feed will not give a color change and will even reduce the color of the fish.

\section{Absolute Weight Growth}

Based on the results of analysis of variance (ANOVA) at the 95\% confidence level, it shows that the absolute weight in the combination treatment of pumpkin flour and carrots shows the results are not significantly different between treatments, this is because the value $(p>0.05)$ The results of data analysis in graphical form can be seen in Figure 2.

Figure 2. Koi Fish Absolute Weight Growth

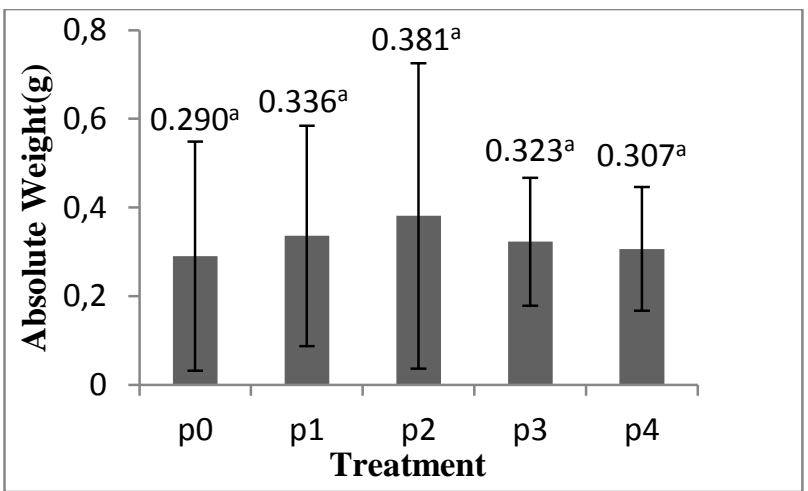

Information: *) numbers followed by the same letter in the same column show that they are not significantly different \pm ) indicates the standard deviation value.

Based on the results of analysis of variance (ANOVA) at the 95\% confidence level, it shows that the absolute weight in the combination treatment of pumpkin flour and carrots shows results that are not significantly different between treatments. However, it can be seen descriptively that the average growth rate of koi fish absolute weight during the study has a different value for each treatment. Based on Table 3 above, the weight of koi fish in treatment $\mathrm{P} 2$ is 0.381 grams, then followed by $\mathrm{P} 1$ treatment with a value of 0.336 grams. Furthermore, P3 is 0.323 grams, then the $\mathrm{P} 4$ value is 0.307 grams and the lowest is $\mathrm{P} 0$ treatment with a value of 0.290 grams.

This increase is because carotenoids also have several other functions such as increasing immunity due to their antioxidant content, a source of vitamin A and prevention of disease (Abramczyk et al. 2016 in Madiara, 2019). Besides the carotenoid content, pumpkin also contains protein, fat, calcium, which can help the growth of koi fish. According to Majid (2010) other content possessed by pumpkin is found in calories, protein, fat, calcium, iron, phosphorus, Vitamin A, Vitamin B, Vitamin C. While the content of carrots according to Taqiyuddin (2015) is the largest component of carrot tubers. carbohydrates are the largest component of solids, then protein, fat and some vitamins and minerals are present in small amounts. Therefore, the addition of a combination of pumpkin flour with carrots does not have a bad effect on fish growth.

\section{Absolute Length Growth}

Based on the results of analysis of variance (ANOVA) at the 95\% confidence level, it showed that the absolute length of the combination treatment of pumpkin flour and carrots showed no significant difference between treatments, this was because of the value ( $p$ > $0.05)$. The results of data analysis in graphical form can be seen in Figure 3.

Figure 3. Value of Absolute Length Growth

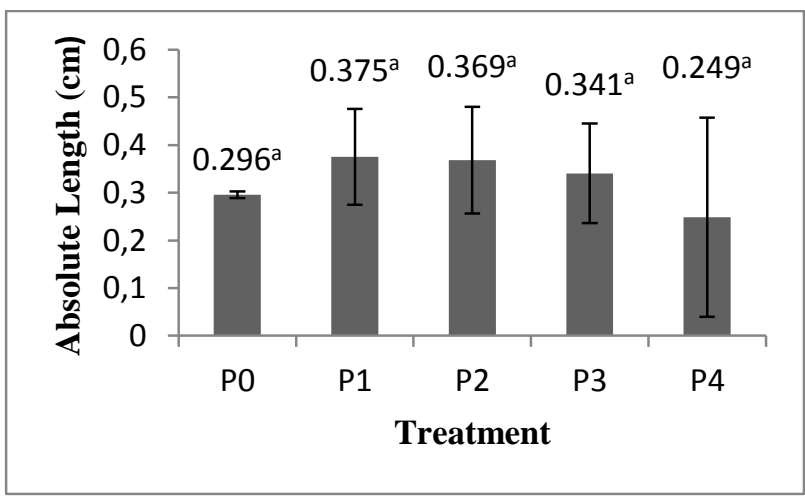

Information: *) numbers followed by the same letter in the same column show that they are not significantly different \pm ) indicates the standard deviation value. 


\section{Survival Rate (SR)}

Based on the results of analysis of variance (ANOVA) at the 95\% confidence level, it shows that the survival rate in the combination treatment of pumpkin flour and carrots showed significantly different results between treatments. The results of data analysis in graphical form can be seen in Figure 4.

Figure 4. Values of Survival

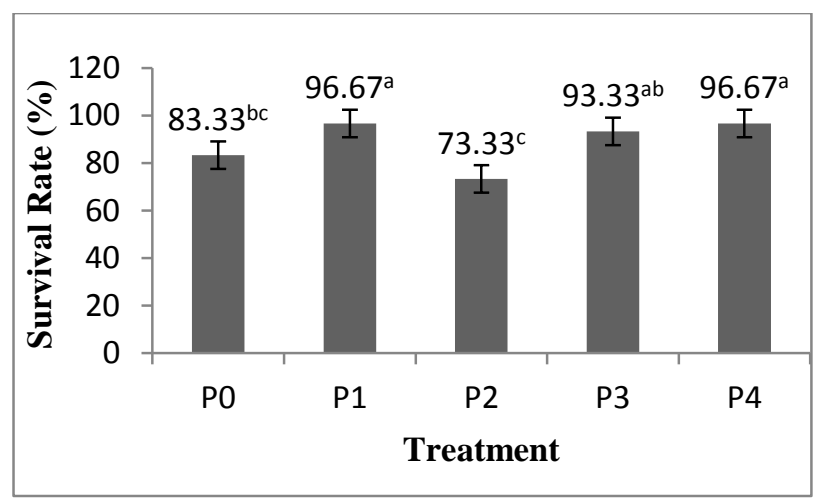

Information: *) numbers followed by the same letter in the same column show that they are not significantly different \pm ) indicates the standard deviation value.

The parameter of a cultivation activity is survival. Survival is the proportion of the number of fish that are still able to survive from the start of rearing until the end of the rearing day. The analysis showed that the addition of pumpkin flour and carrots to the feed had a significant effect on the survival of the koi fish. Data on the proportion of survival for koi fish as long as can be seen in Figure 4.

The highest level of life was in treatment P1 and P4 with an average value of $96.67 \%$, then followed by P3 treatment with an average value of $93.33 \%$, then P0 with an average value of 83.33 , and the lowest survival rate is $\mathrm{P} 2$ with an average value of $73.33 \%$. The high proportion of passing koi fish fry at P1 and P4 is thought to be because at the time of the study it was inseparable from the role of carotene, namely to increase immunity and naturally to provide a color appearance, so that fish are more attractive. However, another function that is no less important physiologically is as a precursor (basic ingredient) of vitamin $\mathrm{A}$, besides that carotene also affects the health of the fish itself (Lesmana, 2002). Meanwhile, the mortality of koi fish seeds in treatment $\mathrm{P} 0$ and $\mathrm{P} 2$ was suspected due to improper handling such as fish from sewage when sampling was carried out and it was suspected that the fish were also stressed during weighing. Fish mortality on the 3rd and 7th day of maintenance, death that occurs due to the slow process of adapting the fish to the new environment in the rearing container. This is in accordance with the statement of Effendi (2002). The survival of fish, especially during the larva and seed period, is largely determined by food data as well as environmental conditions. Fish will experience death without being able to get food and environmental changes that cause stress for fish.

\section{Water Quality}

\begin{tabular}{llccccl}
\hline Parameters & \multicolumn{3}{c}{ Treatment } & References \\
\cline { 2 - 5 } & \multicolumn{1}{c}{ P0 } & P1 & \multicolumn{1}{c}{ P2 } & P3 & P4 & \\
\hline Temp & 27,3 & 27,4 & $27,3-$ & 27,3 & 27,3 & $25-31$ \\
$\left({ }^{\circ} \mathrm{C}\right)$ & - & -28 & 28,6 & - & - & Raharjo \\
& 28,8 & & & 28,6 & 28,1 & $(2016)$ \\
DO (mg/l) & 6,9 & 6,8 & $7,3-7,7$ & 7,3 & 6,9 & $>5$ \\
& - & - & & - & - & Raharjo \\
& 7,7 & 7,6 & & 7,8 & 7,7 & $(2016)$ \\
pH & 7,6 & 7,8 & $7,6-8,6$ & 7,7 & 7,6 & $6,5-8,5$ \\
& - & - & & - & - & Effendi \\
& 8,3 & 8,4 & & 8,3 & 8,5 & $(2003)$ \\
\hline
\end{tabular}

Based on the results of measurements of air quality, temperature, dissolved oxygen and $\mathrm{pH}$ in the aquarium during the study were relatively stable for the survival of koi fish. The range of air quality values obtained during the study ranged from $27.3-28.8^{\circ} \mathrm{C}$, these air quality values 
indicate that koi fish are kept in a suitable and suitable environment for their life. This is in accordance with Agus et al. (2002) in Putriana (2015) who swim in waters, the optimal temperature for the growth of koi fish ranges from 15-25 $\mathrm{C}$ with a $\mathrm{pH}$ ranging from 6.5 - 8.5. Meanwhile, according to Effendi's opinion (1997) in Raharjo (2016), the optimal temperature for fish appetite is $25-27^{\circ} \mathrm{C}$ while for fish survival ranges from $25-31^{\circ} \mathrm{C}$. The value of dissolved oxygen (DO) content ranges from $6.8-7,8 \mathrm{mg} / 1$, this condition is optimal for fish. This is in accordance with the opinion expressed by Boyd (1990) in Raharjo (2016) which states that generally fish live normally at a concentration of $4.0 \mathrm{mg} / 1$, if the oxygen supply is below $20 \%$ of normal needs, the fish will be weak and cause death. According to Effendi (2003), a good oxygen content to optimize fish production is $>5 \mathrm{mg} / \mathrm{L}$. Meanwhile, the $\mathrm{pH}$ value ranges from $7.6-8.3$. This $\mathrm{pH}$ range is very good for the survival of koi fish, according to Effendi (2003), which states that water that is good for fish farming is a neutral range with a $\mathrm{pH}$ of 7.0-8.0. Meanwhile, Agus et al. (2002) in Putriana (2015) who swim in waters that are optimal for koi fish growth ranges from 6.5 - 8.5.

\section{Conclusion}

The addition of pumpkin flour combined with carrot flour to commercial feed gave a significantly different effect on the color of koi fish. In this study, the highest increase in color value in koi fish occurred in $\mathrm{P} 4$ treatment with the addition of a combination of $6 \%$ pumpkin flour and $4 \%$ carrot flour.

\section{Acknowledgements}

I would like to express my gratitude to the Head of the Aquaculture Study Program, Faculty of Agriculture, Mataram University who has provided laboratory facilities and infrastructure assistance. Mutawali Wira and friends colleagues who have helped this research.

\section{Referensi}

Andriani, Y., Alamsyah, A., \& Lili, W. (2018). Effect of Dietary Supplementation of
Spirulina Platensis and Carrot Meal to Enhance Color Brightness of Oranda Goldfish (Carassius Auratus). Jurnal Perikanan dan Kelautan, 8(1), 1-9. https://jurnal.untirta.ac.id/index.php/jpk/a rticle/view/3679

Arianto, R. M., Fitri, A. D. P., \& Jayanto, B. B. (2018). Pengaruh Aklimatisasi Kadar Garam terhadap Nilai Kematian dan Respon Pergerakan Ikan Wader (Rasbora argyrotaenia) untuk Umpan Hidup Ikan Cakalang. Journal of Fisheries Resources Utilization Management and Technology, 7(2), 43-51. https://ejournal3.undip.ac.id/index.php/jfr umt/article/view/20525

Azuri, R., Rusliadi, \& Iskandar (2018). Pengaruh Penambahan Tepung Labu Kuning (Carcurbita sp.) pada Pakan Dengan Dosis yang Berbeda terhadap Kecerahan Warna Ikan Botia (Chromobotia machracanthus). Jurnal Perikanan dan Kelautan. Fakultas Perikanan

Deriyanti, A. (2016). Korelasi Kualitas Air dengan Prevalensi Myxobolus pada Ikan Koi (Cyprinus carpio) di Sentra Budidaya Ikan Koi Kabupaten Blitar, Jawa Timur. Skripsi. Unpublish. Fakultas Perikanan dan Ilmu Kelautan, Universitas Airlangga. Surabaya.

Fitrianingsih, E., Haryanto, H., \& Setyono, B. D. H. (2013). Pengaruh Pakan yang Berbeda Terhadap Pertumbuhan dan Sintasan Ikan Badut (Amphiprion ocellaris). Jurnal Perikanan Unram, 1(2), 13-19. http://jperairan.unram.ac.id/index.php/JP/ article/view/22

Muharam, E. G., Buwono, I. D., \& Mulyani, Y. (2012). Analisis Kekerabatan Ikan Mas Koi (Cyprinuscarpio Koi) Dan Ikan Mas Majalaya (Cyprinuscarpio Carpio) Menggunakan Metode Rapd. Jurnal Perikanan Kelautan, 3(3). http://journal.unpad.ac.id/jpk/article/view/ $\underline{1393}$ 
Haikal, F.L., \& Mulyana (2008). Koi Panduan Pemeliharaan, Galeri Poto, dan Tips Tampil Cantik. Penebar Swadaya. Jakarta: $188 \mathrm{hlm}$.

Kusrini, E., Cindelaras, S., \& Prasetio, A. B. (2015). Pengembangan Budidaya Ikan Hias Koi (Cyprinus Carpio) Lokal Di Balai Penelitian Dan Pengembangan Budidaya Ikan Hias Depok. Media Akuakultur, 10(2), 71-78. http://ejournalbalitbang.kkp.go.id/index.php/ma/article/ view/958

Madiara, F., Darsiani, Takril, \& Arbit, N.I.S. (2019). Peningkatan Kualitas Warna pada Ikan Maskoki Karena Penambahan Tepung Labu Kuning terhadap Pakan Buatan. Jurnal Ilmiah Samudra Akuatika. 3(1): 17-22.

Majid, R. (2010). Analisis Perbandingan Kadar $\beta$-karoten dalam Buah Labu Kuning (Cucurbita moschata) Berdasarkan Tingkat Kematangan Buah Secara Spektrofotometri Uv-Vis. Skripsi. Unpublish. Fakultas Ilmu Kesehatan. Universitas Islam Indonesia Alauddin. Makassar.

Maolana, V., Madyowati, S.O., Hayati, N. 2017. Pengaruh Penambahan Air Perasan Wortel (Daucus Carota L.) dalam Pakan terhadap Peningkatan Warna pada Pembesaran Ikan Koi (Cyprinus carpio) di Desa Gandusari Kecamatan Gandusari Kabupaten Blitar. Jurnal Techno-Fish, 1(2):78-85.

Mas'ud, F. (2011). Prevalensi dan Derajat Infeksi Dactylogyrus sp. pada Insang Benih Bandeng (Chanos chanos) di Tambak Tradisional, Kecamatan Glagah, Kabupaten Lamongan. Jurnal Ilmiah Perikanan dan Kelautan. 3(1): 27-39. https://e-

journal.unair.ac.id/JIPK/article/view/1161 $\underline{6 / 6625}$

Nugroho, E., \& A. H. Kristano. (2008). Panduan Lengkap Ikan Konsumsi Air Tawar
Populer. Penebar Swadaya. Jakarta: 168 hlm.

Nurhayati, N., Fauziyah, F., \& Bernas, S. M. (2016). Hubungan Panjang-Berat dan Pola Pertumbuhan Ikan di Muara Sungai Musi Kabupaten Banyuasin Sumatera Selatan. Maspari Journal, 8(2), 111-118. https://core.ac.uk/download/pdf/2678218 49.pdf

Nurrahma, Mulyadi, \& Usman M. (2018). Peningkatan Kualitas Warna Pada Ikan Komet (Carassius auratus) Dengan Pemberian Dosis Tepung Wortel yang Berbeda. Jurnal Perikanan dan Kelautan. 4 (2): 12-21.

Purwanto, C.C., Ishartani, D., \& Rahadian, D. (2013). Kajian Sifat Fisik dan Kimia Tepung Labu Kuning (Cucurbita maxima) dengan Perlakuan Blanching dan Perendaman Natrium Metabisulfit $\left(\mathrm{Na}_{2} \mathrm{~S}_{2} \mathrm{O}_{5}\right)$. Jurnal Teknosains Pangan. 2(2): 121-130. https://www.semanticscholar.org/paper/K AJIAN-SIFAT-FISIK-DAN-KIMIA

Putri, S.R. (2018). Pengaruh Penambahan Tepung Wortel (Daucus sp.) dan Tepung Labu Kuning (Cucurbita sp.) pada Pakan Buatan Terhadap Kualitas Warna Ikan Platy Pedang (Xyphoporus helleri). Skripsi. Fakultas Perikanan dan Kelautan. Universitas Riau. Pekanbaru.

Putriana, N., Tjahjaningsih, W., \& Alamsjah, M.A. (2015). Pengaruh Penambahan Perasan Paprika Merah (Capsicum annuum) dalam Pakan terhadap Tingkat Kecerahan Warna Ikan Koi (Cyprinus Carpio L.). Jurnal Ilmiah Perikanan dan Kelautan. 7 (2): 189-194.

Raharjo, E.I., Farida, \& Raharjo, T.P.T.E.I (2016). Pengaruh Beberapa Jenis Pakan Alami terhadap Pertumbuhan dan Kelangsungan Hidup Larva Ikan Koi (Cyprinus carpio). Jurnal Ruaya. 4 (2): 2541-3155. 
Ramadhani (2015). Analisis Pencemaran Kualitas Air Sungai Bengawan Solo Akibat Limbah Industri, Dikecamatan Kebakkramat. Universitas Brawijaya Malang.

Rimalia, A. (2016). Variasi Pemberian Probiotik Dalam Pakan Terhadap Kelangsungan Hidup Benih Ikan Mas (Cyprinus carpio L). Media Sains. 9 (1): 85-91

Saputri, D. A., \& Mutiarasari, A. (2017). Pengaruh Pemberian Kombinasi Tepung Wortel (Daucus cartota) dan Tepung Labu Kuning (Chucrbita moscata D.) terhadap Warna pada Ikan Koi. Jurnal Pendidikan Biologi: Bioedukasi. 8 (2): 163-170. https://ojs.fkip.ummetro.ac.id/index.php/b iologi/article/view/1074

Sinjal, H. (2014). Efektivitas Ovaprim Terhadap Lama Waktu Pemijahan, Daya Tetas Telur Dan Sintasa Larva Ikan Lele Dumbo (Clarias gariepinus). Jurnal Budidaya Perairan. $\quad 2 \quad$ (1): $14-21$. https://ejournal.unsrat.ac.id/index.php/bd p/article/view/3788

Sitorus, A.M.G. (2014). Pengaruh Konsentrasi Astaxanthin pada Pakan Terhadap Peningkatan Warna Ikan Mas Koki (Crassius auratus). Skripsi. Unpublish. Program Studi Manajemen Sumberdaya Perairan Fakultas Pertanian, Universitas Sumatra Utara.

Solihah, R., Buwono, I. D., \& Herawati, T. (2015). Pengaruh Penambahan Tepung Labu Kuning Dan Tepung Kepala Udang Terhadap Peningkatan Kualitas Warna Ikan Mas Koki (Carassius auratus). Jurnal Perikanan Kelautan, 6(2 (1)). http://jurnal.unpad.ac.id/jpk/article/view/8 $\underline{788}$

Taqiyuddin M. Z. (2015). Analisa $\beta$-Karoten pada wortel (Daucus carota) dengan menggunakan spektrofotometer Tampak. Skripsi. Fakultas Teknik Universitas Diponegoro Semarang.
Wicaksono, A., Arief, M. R., \& Ramdhani, R. A. (2017). Analisis Identifikasi Pola Ikan Koi Menggunakan Metode Sobel Edge Detection. Jurnal Simki-Techsain. 1(6): 29.

Yusniarti, Kurnia, A., \& Muskita, W.H. (2018). Studi Pemanfaatan Tepung Kulit Buah Manggis (Garcinia mangostana L.) untuk Pewarnaan Ikan Hias Komet (Carassius auratus). Jurnal Media Akuatika. 3(2): 659-669. 